\title{
natureouTLOOK BATTERIES
}

29 October 2015 / Vol 526 / Issue No 7575

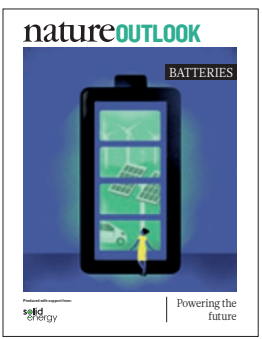

Cover art: Sébastien Thibault

\section{Editorial}

Herb Brody

Brian Owens

Jenny Rooke

Art \& Design

Wesley Fernandes Mohamed Ashour

Kate Duncan

Nigel Hawtin

Production

Karl Smart

lan Pope

Mira Loufti

Sponsorship

Stephen Brown

Samantha Morley

Marketing

Hannah Phipps

Project Manager

Anastasia Panoutsou

Art Director

Kelly Buckheit Krause

Publisher

Richard Hughes

Chief Magazine Editor Rosie Mestel

Editor-in-Chief

Philip Campbell
$\mathrm{T}$ The ability to chemically store energy that can be accessed on demand has transformed the way we power our world, driving us to develop ever-smaller, more powerful and portable electronic devices, and freeing us from being tethered to a grid by wires.

An even greater revolution may be in store, allowing us to substitute intermittent renewable-energy sources for fossil fuels, and bringing more electric vehicles to the roads. For this to happen, scientists will need to radically increase batteries' energy density, reliability and safety (see page S92). Lithiumion batteries have led the way for the past 30 years, and may be reaching the limits of their abilities. But researchers have not given up on them yet, seeking out new chemical configurations to squeeze more power out of the cells (page S93).

One hope is that solid materials can replace the liquid electrolyte in many batteries, including some lithium ones, to make them safer, more flexible and more powerful (page S96). Going in the other direction, flow batteries replace solid electrodes with liquids; this approach makes it easy to increase energy capacity by adding larger tanks, which can be swapped out for rapid recharging (page S98).

As the number of batteries rises, we will need to find ways to deal with them as they reach the end of their lives. Methods to recycle batteries, and the political and economic will to make the practice widespread, are sorely needed (page S100). Batteries can also be avoided entirely. With smarter, connected management of energy use, the electricity grids of the future could accommodate fickle sources of power such as solar and wind without having to store any of it in a battery (page S102).

We are pleased to acknowledge the financial support of SolidEnergy Systems Corp. in producing this Outlook. As always, Nature retains sole responsibility for all editorial content.

\section{Brian Owens}

Contributing Editor
Nature Outlooks are sponsored supplements that aim to stimulate interest and debate around a subject of interest to the sponsor, while satisfying the editorial values of Nature and our readers' expectations. The boundaries of sponsor involvement are clearly delineated in the Nature Outlook Editorial guidelines available at go.nature.com/e4dwzw

CITING THE OUTLOOK

Cite as a supplement to Nature, for example, Nature Vol. XXX, No. XXXX Suppl., Sxx-Sxx (2015).

VISIT THE OUTLOOK ONLINE

The Nature Outlook Batteries supplement can be found at http:// www.nature.com/nature/outlook/batteries

It features all newly commissioned content as well as a selection of

relevant previously published material.
All featured articles will be freely available for 6 months. SUBSCRIPTIONS AND CUSTOMER SERVICES For UK/Europe: Nature Publishing Group, Subscriptions, Brunel Road, Basingstoke, Hants, RG21 6XS, UK. Tel: +44 (0) 1256329242 Subscriptions and customer services for Americas - including Canada, Latin America and the Caribbean: Nature Publishing Group, 75 Varick St, 9th floor, New York, NY 10013-1917, USA Tel: +18663637860 (US/Canada) or +1 2127269223 (outside US/Canada). Japan/China/Korea: Nature Publishing Group Asia-Pacific, Chiyoda Building 5-6th Floor, 2-37 Ichigaya Tamachi, Shinjuku-ku, Tokyo, 162-0843, Japan. Tel: +81 332678751 CUSTOMER SERVICES

Feedback@nature.com

Copyright $\odot 2015$ Nature Publishing Group

\section{CONTENTS}

\section{S9O RESEARCH}

From gadgets to the smart grid

Overcoming batteries' limitations

S92 PERSPECTIVE

The energy-storage revolution

The energy grid could be transformed by the next battery revolution, says George Crabtree

\$93 LITHIUM BATTERIES

To the limits of lithium

Lithium batteries could have ten times the power of conventional ones

\$96 TECHNOLOGY

A solid future

Solid batteries hold promise for massmarket electric cars

S98 ELECTROCHEMISTRY

Liquid assets

The potential of flow batteries

S100RECYCLING

Lazarus batteries

Scientists are developing ways to recover useful parts of old batteries

S102 ENERGY STORAGE

Power revolution

Alternatives to storage could be the answer to a constant renewable supply

\section{S105BATTERIES}

4 big questions

Key research areas

\section{COLLECTION}

S107 An ultrafast rechargeable aluminiumion battery

M.-C. Lin et al.

S111 A pomegranate-inspired nanoscale design for large-volume-change lithium battery anodes N. Liu et al.

S117 The role of graphene for electrochemical energy storage R. Raccichini, A. Varzi, S. Passerini \& B. Scrosati

S126 Interconnected hollow carbon nanospheres for stable lithium metal anodes

G. Zheng et al. 